\title{
PERANAN KOMUNIKASI GURU DALAM IMPLEMENTASI KURIKULUM 2013
}

\author{
Dina Sekar Vusparatih \\ Marketing Communication Department, Faculty of Economic and Communication, BINUS University \\ Jln. KH. Syahdan No.9 Palmerah, Jakarta Barat 11480 \\ dinasekar@yahoo.com
}

\begin{abstract}
ABSTRAK
Curriculum 2013 has been officially implemented in all schools in Indonesia. This curriculum has quite a fundamental change in the competencies to be achieved. These changes lead to changes in the profile of students and teachers are expected. These changes lead to conversion in the expected profile of students and teachers. Teacher, a leading role in the successful implementation of the curriculum in schools, is required to create an interactive learning environment in which students and teachers participate actively. The additional hours of study is intended to provide sufficient time for the two-way communication. However, most of the teachers are not ready to create an active space of two-way communication. In fact, the communication competency is the first competency to be achieved in the curriculum in 2013 and became an important teaching method during the learning process. Therefore, the communication ability of the teachers is very important in the success of the implementation of Curriculum 2013. Teachers must be able to communicate effectively in accordance with their role as a leader and facilitator in the classroom. Giving explanations, asking questions and listening are three effective communication techniques that should be owned by the teacher during this 2013 curriculum. If all three techniques have been mastered and can be implemented correctly then the target of Curriculum 2013 can be achieved.
\end{abstract}

Keywords: curriculum 2013 implementation, teachers' role, effective communication

\begin{abstract}
ABSTRAK
Kurikulum 2013 telah resmi diimplementasi di seluruh sekolah di Indonesia. Kurikulum ini mempunyai perubahan yang cukup mendasar yaitu pada kompetensi yang akan dicapai. Perubahan ini menyebabkan berubahnya profil siswa dan guru yang diharapkan. Guru sebagai pemeran utama dalam keberhasilan pelaksanaan kurikulum di sekolah, dituntut untuk dapat menciptakan lingkungan belajar yang interaktif dimana siswa dan guru berpartisipasi aktif. Adanya penambahan jam belajar ditujukan untuk menyediakan waktu yang cukup bagi terjadinya komunikasi dua arah. Namun hampir sebagian besar guru belum siap untuk menciptakan ruang berkomunikasi aktif dari dua arah. Sementara kompetensi berkomunikasi adalah kompetensi pertama yang ingin dicapai dalam Kurikulum 2013 dan menjadi metode pengajaran penting selama proses belajar mengajar. Oleh karena itu, kemampuan berkomunikasi guru sangat berperan dalam menunjang keberhasilan pelaksanaan Kurikulum 2013. Guru harus mampu berkomunikasi secara efektif sesuai dengan peranannya sebagai pemimpin dan fasilitator di kelas. Penjelasan, memberi pertanyaan dan mendengarkan adalah tiga tenik berkomunikasi efektif yang seharusnya dimiliki oleh guru pada masa Kurikulum 2013 ini. Jika ketiga teknik telah dapat dikuasai dan diimplementasikan dengan benar maka target dari Kurikulum 2013 dapat tercapai.
\end{abstract}

Kata kunci: implementasi kurikulum 2013, peranan guru, komunikasi efektif 


\section{PENDAHULUAN}

Menjelang tahun ajaran 2013/2014, dunia pendidikan di Indonesia terasa lain dari biasanya. Kali ini, bukan hanya orang tua yang kerepotan untuk mencari sekolah bagi anak mereka yang mulai masuk bangku sekolah atau naik ke tingkatan pendidikan yang lebih tinggi, tapi kepala sekolah dan guru-guru pun juga kerepotan. Adanya Kurikulum 2013 yang terasa sedikit dipaksakan untuk segera diimplemetasikan pada tahun ajaran 2013/2014 membuat mereka cukup kerepotan. Dari sisi pemerintah sendiri melalui Dinas Pendidikan di setiap provinsi telah aktif mengadakan sosialisasi dan pelatihan implementasi Kurikulum 2013.

Telah ditetapkan bahwa Kurikulum 2013 akan tetap mulai diimplementasikan pada tahun ajaran 2013/2014 di semua tingkat sekolah yaitu SD, SMP, dan SMA/SMK. Mulai dari 15 Juli 2013 Kurikulum 2013 resmi diberlakukan di 6.329 sekolah dari jenjang SD hingga SMA di Indonesia (Fathur Rokhman, 2013). Pemerintah terutama jajaran di Kementerian Pendidikan dan Budaya sangat optimis bahwa semua sekolah di seluruh Indonesia sudah siap mengadopsi kurikulum tersebut.

Hal ini diperkuat dengan pernyataan Mendikbud Prof. Dr. Ir. Muhammad Nuh dalam berbagai kesempatan bahwa Kurikulum 2013 telah dirancang sedemikian rupa agar siswa mampu meraih kompetensi utama, yakni sikap, pengetahuan, dan keterampilan (afektif, kognitif, dan psikomotor). (Rokhman, 2013). Dengan berpegangan pada tujuan dan hasil yang lebih baik dan sesuai dengan perkembangan jaman inilah, yang membuat Kurikulum 2013 tetap akan diimplementasi.

Memang pada faktanya Dinas Pendidikan provinsi melalui staf bagian kurikulum sangat aktif melaksanakan pelatihan implementasi. Namun masih saja terdengar disana sini sikap-sikap pesimis atau komentar yang sinis mengenai kurikulum yang dirasakan terlalu dipaksakan. Guru yang belum siap atau perubahan isi dalam kurikulum yang dinilai mengkerdilkan mata pelajaran lain, merupakan contoh komentar negatif mengenai kurikulum ini. Tetapi tidak sediit pula yang justru menilai positif isi dari kurikulum baru yang dinilai membangkitkan kembali nilai-nilai budi pekerti siswa dan tidak membebani siswa karena jumlah mata pelajaran dikecilkan namun menambahkan mata pelajaran dan jam pelajaran pada mata pelajaran tertentu. Dengan adanya tambahan jam belajar ini dan pengurangan jumlah Kompetensi Dasar, guru tentu memiliki keleluasaan waktu untuk mengembangkan proses pembelajaran yang berorientasi siswa aktif belajar. Proses pembelajaran siswa aktif memerlukan waktu yang lebih panjang dari proses pembelajaran penyampaian informasi karena peserta didik perlu latihan untuk melakukan pengamatan, bertanya, berasosiasi, dan berkomunikasi. (Rokhman, 2013)

Secara garis besar, Kurikulum 2013 memang lebih memfokuskan pada beberapa mata pelajaran tertentu dan menghilangkan atau mengurangi jam pelajaran untuk mata pelajaran lainnya. Hal ini ditujukan agar siswa dapat lebih fokus dan tidak terbebani dengan terlalu banyaknya tuntutan dari berbagai macam mata pelajaran. Dari sisi guru, Kurikulum 2013 juga mengubah peranan guru di kelas menjadi seorang fasilitator sehingga tidak lagi menjadi satu-satunya pusat informasi di kelas. Metode komunikasi satu arah seperti berbicara sendiri di depan kelas atau mendikte, tidak lagi tepat untuk dilakukan. Menciptakan kelas menjadi lebih interaktif dimana siswa lebih aktif berbicara dan mencari berbagai informasi dari berbagai sumber, merupakan fungsi dan peranan guru yang harus diimplementasi dalam Kurikulum 2013 ini.

Tapi apakah para guru sudah siap untuk berganti peran yang semula berbicara searah menjadi seorang fasilitator yang harus memfasilitasi siswanya untuk memperoleh berbagai ilmu dan keahlian? Atau mau berbagi peran dan waktu dalam berbicara di kelas? Sementara sudah sejak lama metode pengajaran di Indonesia memang menjadikan guru sebagai dewa dan satu-satunya sumber informasi. Penjelasan dengan metode komunikasi satu arah adalah satu-satunya pengajaran yang dianggap efektif. Memang masih ada beberapa guru yang mencoba lebih kreatif dan mengimplementasi metode 
mengajar yang lebih interaktif dan membuat siswa lebih aktif. Namun biasanya hal ini dilakukan oleh guru-guru dari sekolah swasta yang memang dituntut untuk memberi pelayanan lebih ke siswa dan orang tua karena iuran SPP yang juga lebih mahal dari sekolah negeri. Namun, jumlah guru-guru yang seperti ini hanya sebagian kecil dan bahkan tidak semua sekolah swasta mempunyai guru seperti itu atau mendukung gurunya untuk lebih interaktif. Sementara ketika membicarakan Kurikulum 2013, kita membicarakan seluruh guru di Indonesia dimana sebagian besar masih menggunakan metode pengajaran satu arah.

Dari gambaran tersebut akhirnya dapat disimpulkan bahwa keberhasilan pelaksanaan Kurikulum 2013 sepenuhnya bergantung kepada kompetensi guru terutama kompetensi komunikasinya. Peningkatan kompetensi komunikasi tidak hanya diharapkan dari sisi guru tetapi juga diharapkan dari sisi siswa. Kompetensi berkomunikasi baru akan tercapai jika memang siswa terbiasa berkomunikasi secara aktif. Untuk membuat siswa berkomunikasi secara aktif dan efektif, pada akhirnya, hal ini bergantung sepenuhnya pada bagaimana guru dapat menciptakan suasana belajar yang aktif sehingga dapat menstimulus siswa untuk turut aktif berpartisipasi dalam proses komunikasi di semua kegiatan belajar mengajar. Guru berperan untuk menggali kemampuan berkomunikasi siswa sehingga setelah lulus sekolah, siswa mampu berkomunikasi dengan lingkungan sekitarnya. Namun apakah guru juga sudah mempunyai kemampuan berkomunikasi yang mumpuni untuk melaksanakan Kurikulum 2013? Melihat dari yang sedang terjadi saat ini, memang masih sulit untuk mengatakan bahwa guru sudah siap berganti peran. Namun guru tidak bisa mengatakan tidak atau jangan dulu. Mereka harus siap mengubah peran dan meningkatkan kompetensi komunikasinya agar dapat menjadi guru yang tepat dalam menjalankan Kurikulum 2013. Lalu seperti apakah peranan guru dalam implementasi sebuah kurikulum? Dan bagaimana komunikasi yang efektif sebagai seorang guru di kelas?

\section{METODE}

Sebuah penelitian memerlukan metode dalam pelaksanaannya. Untuk jurnal penelitian ini, dirasakan tepat menggunakan pendekatan penelitian kualitatif. Pendekatan kualitatif adalah pendekatan yang benar-benar memperlakukan obyek yang diteliti sebagai subyek bukan obyek (Raco, 2010; 8). Oleh karena itu, guru disini benar-benar diperlakukan sebagai subyek. Semua pernyataan dari guru akan sepenuhnya menjadi sumber data. Selanjutnya Sugiyono (2011:15), menyimpulkan bahwa metode penelitian kualitatif adalah metode penelitian yang berlandaskan pada filsafat post positivism, digunakan untuk meneliti pada kondisi obyek yang alamiah, (sebagai lawannya eksperimen) dimana peneliti adalah sebagai instrumen kunci, pengambilan sampel sumber data dilakukan secara purposive dan snowball, teknik pengumpulan dengan trianggulasi (gabungan), analisis data bersifat induktif/kualitaif, dan hasil penelitian kualitatif lebih menekankan makna dari pada generalisasi.

Pada jurnal penelitian ini, cara pengambilan sumber data adalah purposive dimana pemilihan narasumber sudah ditentukan oleh peneliti, yaitu guru-guru di sekolah negeri. Pada dasarnya implementasi Kurikulum 2013 wajib bagi sekolah-sekolah negeri dan hal ini akan membuat implementasi tersebut akan sangat terasa pada sekolah-sekolah negeri. Selain itu, perubahan peranan guru yang menjadi lebih terbuka dan tidak lagi menjadi satu-satunya sumber akan sangat dirasakan oleh para guru negeri. Mereka telah terbiasa dengan stigma bahwa guru adalah dewa di sekolah dan apapun metode mengajar yang digunakan akan selalu benar dan tidak bisa diganggu gugat. Kalaupun metode mengajar seorang guru itu tidak baik, sanksi paling berat hanyalah mutasi atau pengurangan jam mengajar, tidak akan lebih buruk dari itu. Hal ini terjadi karena status sebagai Pegawai Negeri Sipil (PNS) hanya bisa digoyahkan atau dibatalkan jika menyangkut tindakan kriminal atau asusila. Hal ini berbeda dengan guru dari sekolah-sekolah swasta yang memang lebih dituntut untuk lebih 
interaktif. Performa yang tidak baik akan berdampak langsung pada karir guru di sekolah swasta seperti tidak diperpanjang kontrak.

Sementara metode penelitian yang dipilih adalah fenomenologi. Penelitian fenomenologi adalah berusaha memahami arti peristiwa dan kaitan-kaitannya terhadap orang-orang biasa dalam situasi-situasi tertentu (Moleong, 1988; 7-8). Fokus dalam penelitian fenomenologi adalah apa yang dialami oleh subjek penelitian terhadap apa yang dialaminya dan bagaimana subjek mengalami dan memaknai pengalamannya itu.

Teknik pengumpulan data sebagaimana penelitian dalam pendekatan kualititatif, menggunakan teknik wawancara, observasi dan penelusuran dokumen. Sementara analisa datanya menggunakan teknik deskriptif. Pendekatan yang digunakan adalah bersifat kualitatif yang memiliki karakteristik bersifat deskriptif. Data yang yang dikumpulkan berupa pertama langsung dari sumbernya, peneliti menjadi bagian dari instrumen pokok analisisnya, kedua data berupa kata-kata dalam kalimat atau gambar yang mempunyai arti (Sutopo, 2006).

\section{HASIL DAN PEMBAHASAN}

\section{Kurikulum 2013}

Dalam proses belajar mengajar di sekolah, peranan kurikulum adalah yang paling utama. Ibarat seseorang yang hendak menggapai mimpi, kurikulum adalah mimpinya. Dalam kurikulum terkandung seperti apa manusia yang terlahir setelah lulus dari bangku SMA dan bagaimana cara membentuk manusia itu. Menurut Colin Marsh, kurikulum didefinisikan sebagai sebuah produk dokumen dimana didalamnya terdapat tujuan akhir, tujuan jangka pendek, isi/kandungan, teknik mengajar, evaluasi dan penilaian, dan sumber belajar. Terkadang, dokumen ini dikeluarkan secara resmi oleh pemerintah atau sebuah agen dimana didalamnya menjelaskan APA dan BAGAIMANA. (Marsh, 2000)

Berdasarkan definisi tersebut dapat disimpulkan bahwa kurikulum adalah panduan untuk para guru mengenai tentang apa yang mau dicapai dan bagaimana caranya. Melalui penjelasan teknik mengajar di dalam kurikulum maka secara tidak langsung para guru diarahkan untuk mempunyai metode pengajaran yang seragam dan sesuai dengan tujuan akhir yang akan dicapai. Oleh karena itu, pemerintah berharap manusia Indonesia yang terlahir melalui media sekolah akan seragam pula di seluruh Indonesia.

Kurikulum di Indonesia sendiri seringkali mengalami perubahan. Bahkan sering kita dengar komentar-komentar nyinyir yang mengatakan kurikulum di Indonesia bergantung pada pergantian menteri pendidikan. Setiap menteri diganti maka diganti pula kurikulumnya. Setelah sebelumnya menggunakan Kurikulum KBK (Kurikulum Berbasis Kompetensi) yang dimulai pada tahun 2004, pemerintah kemudian mengubahnya menjadi Kurikulum KTSP (Kurikulum Tingkat Satuan Pendidikan) pada tahun 2006. Lalu pada awal tahun 2013, sesuai dengan Permendikbud no 54 tahun 2013, pemerintah membatalkan Permendikbud no 23 tahun 2006 tentang Standar Kompetensi Lulusan (SKL) untuk Satuan Pendidikan Dasar dan Menengah (http://bsnp-indonesia.org/id). Pembatalan SKL tahun 2006 ini merupakan langkah untuk beralih ke kurikulum baru yaitu Kurikulum 2013. Kemudian pemerintah mulai mengumumkan adanya Kurikulum 2013 yang akan segera diimplementasi segera di tahun ajaran 2013.

Kurikulum 2013 adalah kurikulum berbasis kompetensi, outcomes-based curriculum, oleh karena itu pengembangannya dirumuskan dalam Standar Kompetensi Lulusan. (Enny, 2013) Dari 
sembilan kompetensi di masa depan yang harus dimiliki oleh siswa/i Indonesia, kompetensi yang paling pertama adalah kompetensi berkomunikasi. Untuk menunjang tercapainya kompetensi tersebut, proses pembelajaran pun harus berubah. Beberapa alasan rasional mengapa Kurikulum 2013 dinilai lebih baik, sebagaimana yang dipaparkan oleh Kemendikbud dalam draf Kurikulum 2013 yang dikeluarkan pada November 2012, adalah adanya perubahan proses pembelajaran dan proses penilaian. Proses pembelajaran yang dimaksud adalah siswa tidak diberi tahu tetapi mencari tahu. Perubahan juga terjadi pada proses penilaian dimana tidak lagi berbasis output tetapi menjadi berbasis proses dan output. Efek perubahan dari sisi proses pembelajaran dan penilaian ini menuntut proses pembelajaran yang berpusat pada siswa sehingga tercipta suasana belajar yang aktif.

Menilik dari perubahan proses pembelajaran dan proses penilaian dalam Kurikulum 2013, terlihat jelas bahwa akan ada banyak perubahan dalam peranan guru dan siswa di kelas. Siswa mencari tahu dapat diartikan siswa sendiri yang harus berusaha mencari berbagai informasi bukan seperti dulu dimana siswa cukup menunggu diberitahu oleh guru. Cara mencari tahu bisa melalui bertanya, berdiskusi, presentasi, membaca dan berbagai cara-cara kreatif lainnya. Sementara guru tidak lagi berbicara sendiri dan menjadi sumber dari segala sumber. Guru justru hanya menjadi media dan motivator bagi siswa untuk mencari informasi di luar sana. Guru harus mampu memotivasi siswa untuk bertanya, berdiskusi, menyatakan pendapat, menciptakan suasana belajar yang interaktif, menyediakan media belajar yang dapat menstimulus siswa untuk aktif di kelas baik berbicara maupun bereksplorasi. Dengan kata lain, peranan guru menjadi lebih pada seorang fasilitator di kelas agar siswa menjadi lebih partisipatif.

\section{Kurikulum dan Peranan Guru}

Dalam pengembangan sebuah sekolah, hal pertama yang harus dipikirkan adalah konsep sekolah seperti apa yang ingin diwujudkan. Jika poin pertama itu sudah terpenuhi maka tugas berikutnya adalah mencari kurikulum seperti apa yang dapat menjadi jalan terwujudnya konsep tersebut. Setelah kurikulum dirancang maka akan jelas tergambar profil siswa seperti apa yang akan terlahir setelah lulus dari sekolah itu dan tentu saja juga akan tergambar jelas di kurikulum profil guru yang seperti apa yang mampu melaksanakan kurikulum sehingga mampu melahirkan profil siswa yang diinginkan. Oleh karena itu, terlihat jelas bahwa peran guru sangat berkaitan erat dalam pelaksanaan kurikulum.

Sering kita mendengar kalimat bahwa guru adalah garda terdepan sebuah sekolah bahkan ujung tombaknya sekolah. Guru yang memegang peranan penting dalam menyampaikan materi kepada siswa untuk mencapai kompetensi yang ditetapkan kurikulum dalam satu tahun ajaran sekolah bahkan dalam 12 tahun siswa duduk di bangku sekolah. Maka merupakan hal yang wajar jika kurikulum dan guru saling berhubungan.

Rencana kurikulum selama setahun merupakan peta untuk semua mata pelajaran yang dibutuhkan oleh guru untuk satu tahun ajaran sekolah (Glass, 2007). Lebih lanjut Glass menjelaskan mengapa kurikulum dibutuhkan untuk setiap tahun ajaran sekolah, yakni: (1) Menyediakan gambaran besar untuk satu tahun ajaran sekolah; (2) Mengesahkan pengajaran yang standar dan akuntabel, untuk digunakan sebagai petunjuk; (3) Mengindentifikasi kemampuan dan konsep yang ditetapkan dalam standar dan keahlian mengarahkan pertanyaan; (4) Referensi mencapai unit penilaian; (5) Menyediakan daftar dari sumber-sumber dan material yang ada secara keseluruhan; (5) Memberi dukungan dan konsistensi di setiap tingkatan dan menguatkan team work; (6) Mempromosikan artikulasi dari tingkatan ke tingkatan berikutnya; (7) Bertindak sebagai pemasaran dan alat komunikasi.

Dari delapan manfaat kurikulum terhadap guru tersebut, dapat disimpulkan bahwa kurikulum memang menjadi acuan dasar tentang materi apa yang harus diberikan guru kepada siswa dan 
bagaimana guru memberikan materi tersebut sehingga tercapai kriteria siswa yang diinginkan. Hal ini menunjukkan bahwa kurikulum menjelaskan tentang APA dan BAGAIMANA seorang guru menjalankan peranan sebagai tenaga pendidik.

Lalu bagaimana dengan peranan guru dalam pelaksanaan Kurikulum 2013 di Indonesia? Dapat dipastikan bahwa peranan guru dalam Kurikulum 2013 akan berbeda dengan peranan guru dalam kurikulum sebelumnya. Karena sebagaimana yang telah dijelaskan sebelumnya bahwa peranan guru akan berubah secara signifikan akibat dari proses pembelajaran siswa yang juga berubah. Dalam konteks Kurikulum 2013, pelaksanaan APA dan BAGAIMANA seorang guru menjalankan peranan sebagai tenaga pendidik, akan membuat para guru melihat diri mereka dari perspektif yang berbeda. Guru akan lebih menjadi fasilitator dan tidak lagi melakukan pengarahan satu arah dan siswa tidak lagi hanya bersikap menunggu untuk diberitahu. Proses penyebaran informasi dan ilmu pengetahuan akan menjadi dua arah dimana siswa pun diberi ruang untuk berbicara bahkan memperluas topik pelajaran hari itu melalui pertanyaan-pertanyaan maupun informasi lain yang mereka peroleh dari berbagai sumber. Pertanyaan selanjutnya, apakah guru-guru tersebut sudah siap memainkan peran yang berbeda?

\section{Guru dan Cara Berkomunikasi di Kelas}

Proses belajar mengajar yang dilakukan oleh guru akan senantiasa merupakan proses kegiatan interaksi antara siswa sebagai pihak yang belajar dan guru sebagai pihak yang mengajar. Proses itu sendiri merupakan mata rantai yang menghubungkan antara guru dan siswa sehingga terbina komunikasi yang memiliki tujuan yaitu tujuan pembelajaran. Tujuan pembelajaran sendiri telah termaktub dalam kurikulum.

Guru wajib menciptakan suasana kelas yang interaktif dimana siswa dapat secara aktif berpartisipasi dalam proses belajar mengajar. Dengan tidak lagi menjadi satu-satunya sumber informasi, guru harus mampu menjadi media dalam memfasilitasi siswa untuk mampu secara aktif berkomunikasi dalam upaya memperoleh informasi. Peranan seperti itulah yang kurang lebih akan dilakoni para guru di Indonesia dalam implementasi Kurikulum 2013. Sementara sebelumnya hampir sebagian besar guru menjalankan proses komunikasi satu arah di dalam kelas.

Pada dasarnya komunikasi dilakukan oleh seluruh manusia di dunia dengan berbagai profesi yang ada. Hanya saja model komunikasi yang dilakukan akan berbeda antara satu manusia dengan manusia yang lain dan dari profesi yang satu ke profesi yang lain. Semuanya tergantung pada tujuan dan mekanisme serta prosedur dari profesi yang ada. Profesi guru adalah satu dari kategori profesi yang menjadikan komunikasi sebagai cara utama dalam mencapai target keberhasilannya.

Komunikasi adalah berbagi pesan atau sikap yang menghasilkan kesepahaman antara pengirim dan penerima. (Turney, 1992)

Sementara untuk konteks guru, di dalam kelas, proses berbagi pesan dan sikap ini melibatkan adanya perpindahan informasi secara terus menerus dimana didalamnya terlibat sejumlah orang yang menerima dan mengirim pesan. (Marsh, 2000)

Dalam menjalani peranan atau profesinya, guru memang diharuskan untuk lebih banyak berkomunikasi dengan banyak orang dalam satu ruangan. Proses ini terjadi secara rutin dan selain itu guru juga harus menghadapi berbagai macam karakter dan latar belakang siswa. Selain dengan siswa, guru masih harus mampu berkomunikasi dengan pihak-pihak lain yang terlibat dalam kegiatan rutin di sekolah, seperti orang tua murid, pemerintah, pegawai administrasi sekolah, pegawai kebersihan sekolah, Kepala Sekolah, dan bahkan sesama rekan guru. Berikut adalah gambaran lingkaran komunikasi yang terjadi di lingkungan sekolah. 


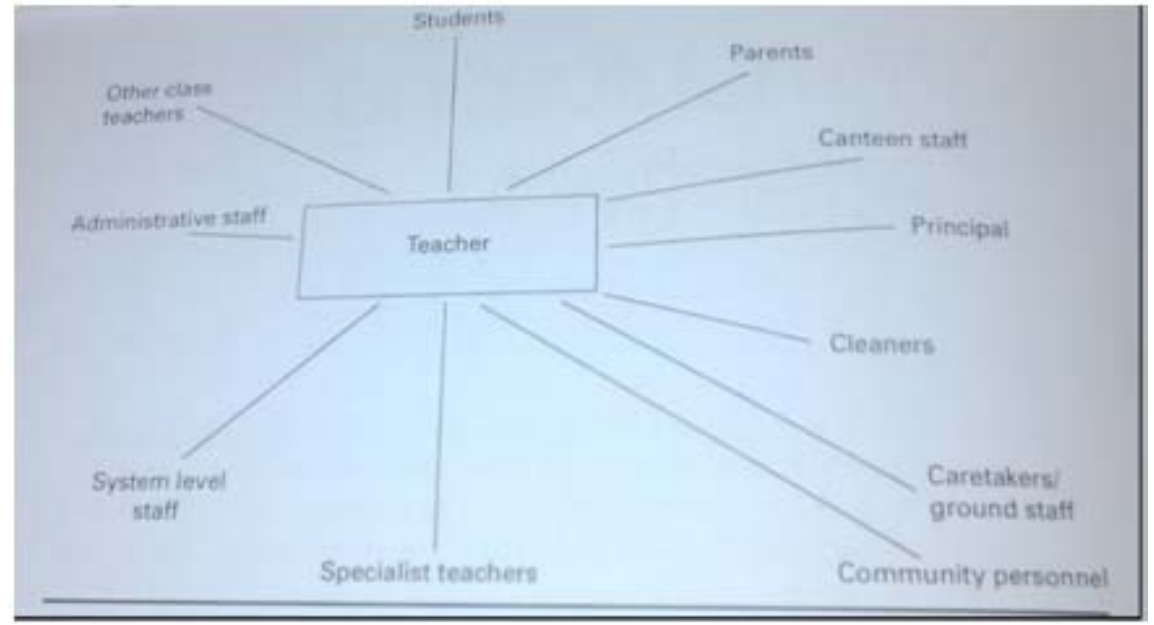

Gambar 1 Lingkaran Komunikasi di Lingkungan Sekolah (Marsh, 2000)

Dari gambaran diatas, sebenarnya kegiatan komunikasi sehari-hariyang dilakukan oleh guru di sekolah termasuk dalam tingkat komunikasi massa.

Komunikasi massa berhubungan dengan komunikator publik. Berbagai aspek yang tercakup di dalam proses komunikasi massa adalah komunikasi interpersonal, komunikasi kelompok, komunikasi publik, dan komunikasi organisasi (Littlejohn, 2005)

Mungkin terlihat terlalu besar jika kita mencoba menempatkan kegiatan komunikasi guru ke dalam tingkat komunikasi massa. Namun memang itulah yang terjadi di lapangan. Dengan rekan sekerja, seorang guru melakukan komunikasi interpersonal. Lalu ketika di kelas, guru akan melakukan kegiatan komunikasi di tingkat kelompok dan publik. Tingkat komunikasi organisasi akan dilakukan oleh guru ketika harus menghadapi Dinas Pendidikan atau orang tua murid dalam rapat karena pada saat itu guru mewakili sekolahnya sebagai sebuah organisasi. Tetapi hal ini memang tidak terlalu tepat karena pada umumnya, komunikasi massa lebih banyak dilakukan oleh mereka yang berprofesi di bidang media massa.

Tingkat komunikasi guru lebih tepat berada pada tingkat komunikasi publik. Hal ini dapat dilihat ketika guru berada di dalam kelas. Tingkat ini lebih mengutamakan kegiatan berkomunikasi melalui presentasi pada sekelompok orang. Bentuknya seperti ceramah, pidato atau orasi. Bentuk komunikasi seperti ini dilakukan oleh hampir semua guru-guru di Indonesia. Komunikasi satu arah dimana guru menjadi satu-satunya sumber informasi. Teknik mengajar lebih menitik beratkan pada ceramah di depan kelas, mendikte materi atau presentasi dengan menggunakan power point. Siswa akan bereaksi dengan duduk diam, mendengarkan dan mencatat, lalu mengerjakan latihan soal yang diberikan oleh guru. Menurut Flanders 1970, sebagaimana dikutip oleh Colin Marsh, komunikasi verbal adalah bentuk komunikasi yang paling banyak digunakan oleh guru-guru. Berdasarkan beberapa penelitian yang telah dilakukan menunjukkan bahwa guru paling banyak berbicara di kelas. Sangat sedikit sekali waktu yang diberikan oleh guru untuk memberikan pertanyaan ke siswa atau menantang siswa untuk lebih terlibat dalam menyelesaikan masalah dan berpikir tingkat tinggi. (Marsh, 2000)

Namun teknik ini menjadi tidak tepat jika kita melihat kembali Kurikulum 2013. Guru diharapkan tidak menggunakan lagi metode komunikasi satu arah namun menggunakan metode komunikasi interaktif. Sebelum membahas lebih lanjut, kita perlu ketahui lebih dulu peranan guru dalam proses belajar mengajar di kelas, yaitu: (1) Sebagai motivator, yaitu memberikan dorongan dan anjuran kepada siswanya agar secara aktif dan kreatif serta positif dalam berintegrasi dengan 
lingkungan atau pengalaman baru berupa pelajaran yang ditawarkan kepadanya; (2) Sebagai fasilitator, yaitu menciptakan suasana dan menyediakan fasilitas yang memungkinkan siswa dapat berinteraksi secara positif dan kreatif dalam proses belajar mengajar; (3) Organisator, yaitu mengatur, merencanakan dan mengorganisasikan kegiatan proses belajar mengajar; (4) Informatory, yaitu memberikan informasi yang diperlukan siswa baik untuk kepentingan dan kelancaran kegiatan proses belajar mengajar maupun untuk kepentingan masa depan siswa; (5) Konselor, yaitu memberikan bimbingan dan penyuluhan atau bantuan khusus kepada siswa yang mempunyai permasalahan dan sebagainya. (Istanto, 2012)

Untuk dapat memenuhi semua peranan guru tersebut, teknik komunikasi yang seperti apakah yang sesuai dan dapat mengakomodir peranan guru sebagai fasilitator? Selain teknik komunikasi yang tepat, guru juga harus menguasai teknik-teknik lain yang mendukung berjalan proses kegiatan belajar mengajar dan yang tidak kalah penting adalah memahami dan mengenali lingkungan kelas tempat kegiatan belajar mengajar.

Lingkungan di dalam kelas harus nyaman dan aman bagi para siswa maupun guru. Jumlah siswa yang terlalu banyak dalam satu kelas dan ruangan kelas yang tidak sehat dan tidak menggambarkan sebuah lingkungan belajar, merupakan komponen-komponen lain yang harus diperhatikan pula demi menciptkan kegiatan belajar mengajar yang efektif. Jumlah maksimum 32 siswa dalam satu kelas adalah jumlah yang paling ideal untuk ukuran tingkat SD, SMP, dan SMA di sekolah-sekolah negeri di Indonesia. Jumlah 32 sampai 35 siswa biasanya menjadi jumlah standar yang digunakan pada sebagian besar sekolah negeri. Fakta ini dapat berbeda jika sekolah swasta yang menjadi standar. Beberapa sekolah swasta menetapkan jumlah 24 siswa sebagai jumlah standar terutama untuk tingkat SD. Sementara jumlah 30 -32 siswa adalah jumlah yang masih bisa ditolerir untuk tingkat SMP dan SMA. Jumlah siswa yang tidak terlalu banyak ataupun tidak terlalu sedikit dapat menghasilkan proses komunikasi yang efektif antara guru dan siswa.

Lingkungan kelas yang terbuka, saling percaya dan mempunyai kesempatan berbicara yang sama bagi siswa dan guru akan menghasilkan sistem berkomunikasi yang efektif di kelas. Guru harus menunjukkan sikap menghargai pendapat atau pertanyaan yang diajukan oleh siswa walaupun pertanyaan tersebut kurang benar atau sepele. Siswa akan mulai memberanikan diri untuk berbicara jika mereka merasa tidak dikecilkan atau disalahkan oleh guru maupun siswa lainnya. Cara berkomunikasi di kelas yang lebih banyak terjadi dari atas ke bawah atau dari guru ke siswa sudah seharusnya berubah menjadi lebih banyak terjadi dari bawah ke atas atau dari siswa ke guru dan juga antar sesama siswa.

Collin Marsh memberikan tiga teknik berkomunikasi efektif bagi guru di dalam kelas, yaitu:

\section{Penjelasan}

Penjelasan adalah aspek paling penting dalam pemberian informasi dari guru ke siswa. Namun aspek ini paling sulit karena seringkali terjadi mispersepsi atau kesalahpahaman dalam memahami sebuah penjelasan tentang sebuah materi. Seringkali guru tidak berusaha untuk menggunakan perspektif siswa dalam mencoba memahami sesuatu karena guru tidak mengetahui teknik yang sesuai/tepat dalam menjelaskan agar mudah dipahami siswa.

Teknik-teknik menjelaskan di kelas adalah: (1) Gunakan langkah-langkah yang logis dalam menjelaskan topik. Gunakan urutan yang masuk akal; (2) Gunakan kalimat langsung dan hindari menggunakan jargon; (3) Jelaskan informasi dalam konnteks yang sesuai dengan siswa; (4) Berikan contoh-contoh agar siswa lebih paham; (5) Ulangi poin-poin yang memang dirasakan sulit dipahami oleh siswa; (6) Gunakan berbagai media komunikasi secara terus menerus dalam memberikan penjelas (ceramah, menggunakan PowerPoint, gambar); (7) Gunakan intonasi suara yang menarik; (8) Gunakan 
kontak mata untuk mempertahankan perhatian siswa; (9) Berikan siswa kesempatan untuk bertanya ketika guru sedang menjelaskan. (Marsh, 2000)

\section{Memberi Pertanyaan}

Memberi pertanyaan adalah teknik yang paling penting bagi guru dan siswa. Melalui bertanya, guru dapat mengetahui sejauh mana siswa memahami topik yang dijelaskan. Sementara melalui bertanya, siswa dapat meminta penjelasan kembali makna dari materi yang kurang dimengerti. Memberi pertanyaan bagi guru mempunyai banyak manfaat, seperti: (1) Dapat membuat siswa tertentu lebih memperhatikan dan berpartisipasi; (2) Menguji pengetahuan siswa terhadap topik tertentu; (3) Meninjau kembali pemahaman siswa terhadap topic; (4) Mengetahui kelemahan siswa; (5) Memotivasi siswa; (6) Membangkitkan beberapa cara berpikir; (7) Membangun rasa aman siswa jika guru yakin bahwa siswa tersebut akan menjawab dengan benar; (8) Mengontrol sikap siswa di kelas. (Marsh, 2000)

Dari manfaat bertanya, guru juga harus mempersiapkan diri dalam memberikan pertanyaan kepada siswa. Guru harus membuat rencana sebelum memberi pertanyaan. Perencanaan seperti menyiapkan pertanyaan yang langsung mengarah kepada topik belajar saat itu, menyiapkan pertanyaan dari yang sulit sampai yang mudah, memastikan urutan pertanyaannya logis, dan memastikan pertanyaan itu jelas dan mudah dimengerti siswa.

Setelah merencanakan pertanyaan yang akan diberikan, masih terdapat hal-hal yang harus diingat oleh para guru ketika bertanya, yaitu: (1) Menulis pertanyaan utama dalam selembar kertas dan selalu merujuk ke kertas tersebut selama pelajaran berlangsung; (2) Berikan pertanyaan satu demi satu; (3) Sediakan waktu yang cukup termasuk waktu untuk siswa bereaksi dalam menjawab pertanyaan; (4) Hindari pertanyaan retorikal; (5) Hindari bertanya ke kelompok siswa tertentu saja. (Marsh, 2000)

Aspek yang paling penting ketika bertanya adalah reaksi guru ketika siswa menjawab. Hal ini sangat penting karena akan berpengaruh pada siswa untuk seterusnya. Ada beberapa reaksi guru dalam menerima jawaban siswa seperti menolak, tidak peduli, membenarkan, merevisi, atau langsung menerima. Hal yang sebaiknya dilakukan guru ketika menerima jawaban siswa adalah menunjukkan sikap yang bersahabat, mendukung secara positif apapun jawaban yang diberikan, dan tidak menunjukkan sikap mengancam apalagi jika jawabannya salah. Guru dapat membantu siswa yang takut, malu atau ragu dalam menjawab pertanyaan dengan memberikan sedikit petunjuk sehingga siswa merasakan bahwa guru bersedia membantunya.

Siswa harus diberikan alokasi waktu yang cukup untuk memberikan pertanyaan. Alokasi waktu dalam memberikan pertanyaan harus berimbang bagi siswa dan guru, Guru tidak boleh mendominasi waktu dalam memberikan pertanyaan. Guru harus dapat memotivasi siswa untuk memberikan banyak pertanyaan kepada guru. Guru juga harus dapat menciptakan suasana yang mendukung siswa untuk berani memberikan pertanyaan. Guru bisa menggunakan teknik berkelompok agar siswa berani memberikan pertanyaan. Teknik kelompok ini adalah dengan melakukan proses belajar kelompok dimana siswa memperoleh kesempatan berkomunikasi dengan rekannya.

\section{Mendengarkan}

Dalam suasana belajar yang mengedepankan komunikasi dua arah, proses mendengar adalah aspek yang penting ketika seseorang berada dalam posisi menerima pesan/informasi. Bahkan guru pun harus mempunyai kemampuan mendengar yang baik, seperti diantaranya: (1) Mencatat beberapa hal penting ketika proses komunikasi berlangsung; (2) Mendengarkan seluruh informasi yang disampaikan dan jangan memberi penilaian awal/menghakimi; (3) Konsentrasi pada pesan utamanya; (4) Jangan terganggu dengan kata-kata yang bersifat emosional yang ikut tersampaikan oleh si 
pengirim pesan; (5) Mempertahkan kontak mata dengan si pembicara; (6) Memberi dukungan positif pada si pembicara baik secara verbal maupun non verbal. (Smith \& Laws, 1992)

Teknik mendengar yang baik mencakup pengetahuan tentang tipe-tipe mendengar yang disesuaikan dengan tujuan kita mendengar. Menurut Pollard dan Tann, terdapat empat tipe mendengar, yaitu: (1) Mendengar interaktif yaitu tipe mendengar ketika berada dalam sebuah diskusi; (2) Mendengar reaktif yaitu tipe mendengar ketika mengikuti instruksi; (3) Mendengar diskriminatif yaitu tipe mendengar ketika mendengarkan music; (4) Mendengar apresiatif yaitu tipe mendengar ketika mendengar sebuah karya seni atau hiburan (Pollard \& Tann, 1987)

\section{SIMPULAN}

Implementasi Kurikulum 2013 mulai tahun ajaran Juli 2013 ini memang banyak menimbulkan polemik terutama di kalangan tenaga pendidik seperti guru dan kepala sekolah. Sosialisasi yang singkat dan diikuti dengan pelatihan-pelatihan singkat ke guru-guru menimbulkan kerepotan hampir di setiap sekolah. Bahkan buku teks sebagai bahan pendukung pun belum siap karena para penerbit juga hanya memiliki waktu yang singkat untuk menyesuaikan isi materi dengan Kurikulum 2013. Kurikulum 2013 memang kurikulum yang terkesan begitu dipaksakan untuk segera diimplementasikan.

Pemerintah atau tepatnya Kementerian Pendidikan dan Kebudayaan merasa sangat yakin bahwa kurikulum KTSP 2006 memang harus segera digantikan oleh Kurikulum 2013 ini. Perkembangan dunia pendidikan di Indonesia dan dunia serta tuntutan zaman terhadap kompetensi siswa, menjadi alasan dirancangnya Kurikulum 2013. Isi dari Kurikulum 2013 sendiri memang memiliki perubahan yang cukup mendasar termasuk mengubah profil siswa dan guru dalam mendukung tercapainya sejumlah kompetensi.

Siswa diharapkan menjadi lebih bersikap mencari tahu dan guru diharapkan menjadi fasilitator di kelas. Beberapa mata pelajaran tertentu dihilangkan namun ada juga penambahan mata pelajaran baru. Selain itu, ada juga penambahan jam pada mata pelajaran tertentu. Upaya ini dilakukan agar tersedia waktu yang lebih banyak dalam proses pembelajaran dimana siswa dapat memperoleh lebih banyak waktu untuk mengasah kemampuan berkomunikasi, mencari informasi, menyelesaikan permasalahan dan berpartisipasi aktif di kelas. Untuk mendukung tercapainya profil siswa seperti itu, guru dituntut untuk mampu menciptakan kelas yang interaktif, mampu menjadi fasilitator, mampu membangkitkan keinginan siswa untuk mencari informasi yang lebih jauh lagi, dan mampu menjadi motivator bagi siswa. Tidak dapat dipungkiri bahwa guru adalah tokoh yang paling penting dalam menjalankan kurikulum di sekolah.

Kendala utama menjalani Kurikulum 2013 bagi guru adalah karena metode pengajaran yang selama ini dilakukan adalah metode pengajaran satu arah. Ceramah yang lebih menggunakan komunikasi satu arah. Banyak berbicara sendiri dan kurang memberi waktu untuk siswa berbicara atau bertanya. Pada implementasi Kurikulum 2013, peranan guru menjadi sebaliknya. Guru diwajibkan tidak terlalu banyak berbicara dan tidak membiarkan siswa menunggu untuk diberi tahu. Sebaliknya guru cukup berbicara seperlunya lalu kemudian menciptakan ruang bagi terjadinya komunikasi dua arah antar guru dan siswa. Komunikasi dua arah dimana guru dan siswa berpartisipasi aktif dalam kegiatan belajar mengajar.

Untuk memperoleh komunikasi dua arah yang efektif dalam proses pembelajaran, guru dapat menggunakan tiga teknik dalam mengajar yaitu teknik ketika menjelaskan, memberi pertanyaan dan mendengar. Proses penjelasan adalah tahapan pertama seorang guru menjelaskan atau memperkenalkan sebuah topik pembelajaran. Ketika menjelaskan, guru sebaiknya menggunakan 
bahasa dan urutan yang logis dan mudah dipahami oleh siswa. Tetap mempertahankan perhatian para siswa selama tahapan penjelasan adalah hal penting lain yang harus diperhatikan. Komunikasi non verbal dari siswa seperti kontak mata atau bahasa tubuh, harus menjadi alarm bagi guru untuk mengetahui kapan harus segera mengubah pola atau teknik ketika sedang memberi penjelasan. Memberi pertanyaan adalah tahapan kedua yang menjadi tahapan terpenting dalam menciptakan suasana yang interaktif. Melalui pemberian pertanyaan, guru dapat mengetahui pemahaman siswa selama proses penjelasan sebelumnya, guru dapat membangkitkan keinginan siswa untuk memberikan pendapat atau contoh yang berkaitan dengan penjelasan, guru dapat menumbuhkan rasa percaya diri siswa untuk lebih berani berbicara, dan guru dapat mengetahui tingkatan pemahaman siswa di dalam kelas. Tahapan terakhir adalah mendengarkan. Ini adalah tahapan yang belum pernah dilakukan guruguru di Indonesia yaitu mendengarkan siswanya. Paradigma bahwa guru adalah yang paling tahu menyebabkan guru tidak mendengarkan siswa. Padahal melalui mendengar pendapat siswa, siswa akan lebih merasa dihargai sehingga akan semakin tertantang untuk terus berbicara dan mencari berbagai informasi lainnya agar dapat menjawab atau memberi pendapat dengan benar.

Implementasi Kurikulum 2013 akan berjalan optimal jika guru mempunyai kemampuan berkomunikasi yang baik. Komunikasi verbal dan non verbal harus dilaksanakan secara seimbang selama proses pembelajaran. Lingkungan kelas yang interaktif dimana guru dan siswa berpartisipasi aktif dalam mencari, memberi, dan menerima informasi, adalah lingkungan yang diharapkan di Kurikulum 2013.

\section{DAFTAR PUSTAKA}

Draft Kurikulum 2013 PPT, diakses dari www.kemendikbud.go.id,

Enny, E. (2013), Peran Guru Dalam Implentasi Kurikulum 2013, diakses dari http://edukasi.kompasiana.com.

Glass, T. (2007). Curriculum Mapping. California, US: Corwn Press.

Istanto, D. (2012) Pentingnya Komunikasi Guru dan Murid. Diakses dari http://dwiistanto.blogspot.com/2012/11/pentingnya-komunikasi-guru-dan-murid.html

Littlejohn, S. (2005). Theories of Human Communication.Canada: Thomson.

Marsh, C. (2000): Handbook for Beginning Teachers. Australia: Pearson.

Rokhman, F. (2013), Harapan Besar Implementasi Kurikulum, diakses dari www.kemendikbud.go.id,

Smith, D. \& Laws, K. (1992). The Communication Role, in Turney, C, Hatton, N., Laws, K., Sinclair, K. \& Smith, D.: The Classroom Manager. Sydney: Allen \& Unwin.

Sugiyono. (2010). Metode Penelitian Pendidikan Pendekatan Kuantitaf, Kualitatif, dan R\&D. Bandung: Alfabeta.

Sutopo HB. (2006). Metode Penelitian Kualitatif. Surakarta: UNS.Press.

Turney, C., Hatton, N., Laws, K., Sinclair, K. \& Smith, D. (1992). The Classroom Manager. Sydney: Allen \& Unwin. 